\title{
Macroinvertebrate Assemblages in Shale-Draining Streams of North- Central Arkansas, USA
}

\author{
George M. Ogendi ${ }^{1, *}$, Robyn E. Hannigan ${ }^{1}$ and Jerry L. Farris ${ }^{2}$ \\ ${ }^{I}$ Department of Chemistry and Program of Environmental Sciences, Arkansas State University, P.O. Box 419, State \\ University, AR 72467 and ${ }^{2}$ Department of Biology, Arkansas State University, P.O. Box 847, State University, AR \\ 72467, USA
}

\begin{abstract}
Natural and anthropogenic release of metals into surface waters and sediments may alter benthic community structure. To better understand macroinvertebrate communities in metal-impacted shale-draining streams in north-central Arkansas, sediment and macroinvertebrate samples were collected from sites on black shale-draining (BLS) and limestone-draining streams (LMS; used as a reference stream). The samples were collected during three sampling occasions targeting periods of stable flows between October 2003 and July 2005. Analyses of metals in water and sediment samples were done according to US EPA 200.8 and 6020 methodologies, respectively. Habitat surveys and macroinvertebrate community sampling, processing and taxonomy were done following US EPA's rapid bioassessment protocols as well as methods outlined in Ohio Environmental Protection Agency. Concentrations of cadmium, copper, and nickel in BLS sediments were significantly $(p<0.05)$ higher than those of LMS samples. The concentrations of cadmium (range: 0.5 $5.3 \mathrm{ppm}$ ), copper (2.2-64), and nickel (6.2-18) in the BLS sediments exceeded the Effect Range-Low values of NOAA's sediment quality guidelines. Except for Chironomidae genera, all macroinvertebrate abundance and richness metrics were significantly lower in BLS than LMS sites $(p<0.05)$. The percent Ephemeroptera-Plecoptera-Trichoptera (EPT) was between two and seven times higher in LMS than BLS sites. The abundance and richness of metal-sensitive taxa (e.g. Heptageniidae and Chloroperlidae) were significantly lower in BLS samples than those of LMS. Negative correlations between sediment metal concentrations and macroinvertebrate richness metrics were also observed. The observed low macroinvertebrate abundance and taxa richness at BLS sites were attributed in part to elevated metal concentrations in sediments and water. Knowledge of the impacts of shale-derived metals on the spatial and temporal distribution of macroinvertebrate is vital in the management of watersheds underlain by black shales. Such information forms the basis upon which sound state and federal government land and water management and conservation policies are made.
\end{abstract}

Key Words: Black shales, weathering, metals, streams, macroinvertebrates, macroinvertebrate abundance and richness metrics.

\section{INTRODUCTION}

Evidence from both field and laboratory studies indicate that metal contamination in streams may alter the composition and structure of macroinvertebrate communities [1-6]. Low total abundance and taxa richness of metal-sensitive macroinvertebrate taxa such as Plecoptera and Trichoptera have been noted in streams characterized by elevated metal levels [2]. Low abundance of metal-intolerant Ephemeropterans (e.g. heptageniid mayflies) is common in streams containing elevated metal concentrations $[2,5,7]$. Other studies have documented high abundance of metal-tolerant chironomids and oligochaetes in metal-contaminated waters and sediments [4, 5, 8-10]. The observed low abundance of metal-sensitive macroinvertebrate taxa have been attributed to increased mortality, diminished growth, and low recruitment $[2,5]$. Some metal-sensitive macroinvertebrate taxa are less impacted by elevated metal concentrations. This includes those taxa become metal-tolerant [11] after prolonged

*Address correspondence to this author at the Department of Chemistry and Program of Environmental Sciences, Arkansas State University, P.O. Box 419, State University, AR 72467, USA; Tel: 870-972-3086 Ext. 2399; Fax: 870-972-3089; E-mail: george1971ke@yahoo.com exposure to elevated metal levels and those that maintain steady populations through wind drift from sites that are unaffected by metals $[4,12]$.

Over the last few decades, macroinvertebrates have been used in assessing impacts of metals from active and abandoned mining sites, thus providing insights on the health of stream ecosystems [2, 5-8]. However, little is known of macroinvertebrate assemblages in streams that are contain elevated metal levels such as those draining metal-enriched rock outcrops. Several studies have shown that physical and chemical weathering of black shales releases potentially toxic metals into the adjacent soils, surface waters and sediments [13-18]. Weathering of black shales may be accelerated by anthropogenic activities in the watershed. Recent studies have shown that water and sediments in streams draining the Mississippian Fayetteville Shale of north-central Arkansas contain elevated metal concentrations that may, under certain conditions, be detrimental to macroinvertebrates and other stream biota $[15,17]$. Whereas the bulk of the metals in water and sediments result from natural geologic processes, the influence of human activities cannot be ignored. The constant release of potentially toxic metals into shale streams warrants continuous monitoring so as to pro- 
tect aquatic fauna and drinking water sources. The study area falls within the Little Red River ecosystem that is habitat to the threatened speckled pocketbook mussel (Lampsilis streckeri) and the yellowcheek darter (Etheostoma moorei). Previous studies by Winterringer [19] and Wine et al. [20] attributed decreased abundance of the two species to impaired water quality in the ecosystem. Elevated concentrations of potentially toxic metals were one probable causes in addition to loss of habitat for the two species. An increase in metal loadings above natural background values is attributable to human activities. Since 2000 , there has been an increase in road construction, agriculture and human settlements in the north-central Arkansas region that is partly underlain by black shales. These human activities have the potential of increasing metal loadings in adjacent streams by accelerating metal release from the black shale outcrops. Thus, the long-term protection and management of aquatic organisms including the threatened species in these aquatic ecosystems depends on being able to determine the temporal and spatial changes in abundance and diversity of aquatic organisms in the adjacent rivers and streams over a long period of time. Biomonitoring is a vital tool in evaluating the exposure and impacts of metal pollutants on aquatic fauna. Knowledge of the spatial and temporal macroinvertebrate assemblages of shale-draining streams and rivers is necessary for the generation of baseline data for appropriate watershed management actions to be taken. Such information will form the basis upon which sound policies with regard to land development in the region can be made.

There is limited knowledge on macroinvertebrate assemblages of shale-draining streams that contain elevated metal levels. In an attempt to understand the impact of metals on benthic macroinvertebrates in shale-draining streams, an integrated study approach was used. This approach incorporated ambient toxicity bioassays to determine the impact of metals in water and sediments, chemical analyses to identify and quantify metal contaminants that exceeded threshold levels, and macroinvertebrate surveys to determine the taxa abundance and richness of macroinvertebrates in the shaledraining streams of north-central Arkansas. The objective of the study was to characterize and contrast macroinvertebrate assemblages in streams draining black shale from those draining limestone in north-central Arkansas.

\section{MATERIALS AND METHODS}

\section{Description of Study Sites}

Sampling sites for this study are located in the headwaters of the Little Red River Watershed in north central Arkansas (Fig. 1). The sites had a preponderance of riffle and run habitats that were predominantly cobble, interspersed with large boulders and /or gravel. Three of the streams (Trace, Begley, and Cove creeks) drain an extensive late Mississippian period ( 350 m.y.a.) Fayetteville Shale outcrop of north-central Arkansas. Riparian vegetation is dominated by oak-hickory, oak-hickory-pine forest association, with occasional interspersions of cedar glades and short-leaf pines. The fourth stream, Mill Creek, is also a bedrock stream that drains late Mississippian period ( 300 m.y.a.) Pitkin Limestone. Channel morphology, habitat, and riparian vegetation characteristics in shale-draining streams were similar to those of Mill Creek (Table 1). Mill Creek was used as a reference stream for this study. Each stream contained two sampling reaches each measuring $100 \mathrm{~m}$ long and was at least $200 \mathrm{~m}$ upstream and /or downstream from any road or bridge crossing or major tributaries discharging to the study streams.

The sampling sites were code-labeled TRA and TRB for Trace Creek; BGA and BGB for Begley Creek; CVA and CVB for Cove Creek; and MLA and MLB for Mill Creek. There were two sampling locations (denoted by numbers 1 or 2 preceded by the code for the reach; see Fig. (1)) within each sampling reach. In summary, the four streams represented the experimental units while the coded sites represented the subsamples in their respective stream reaches. For instance, subsamples TRA1 and TRA2 were collected in stream reach $\mathrm{A}$ in Trace Creek were composited to arrive at some mean value representing this site.

\section{Sampling and Processing of Macroinvertebrates}

Sampling for benthic macroinvertebrates was done between October 2003 and July 2005, and targeted periods of stable base flows in the streams. Macroinvertebrates were sampled from riffles due not only to the diversity of substratum types found there, but also because preliminary habitat classification indicated that the study streams were dominated by riffles and runs. Six replicate benthic samples per reach site (e.g. TRA) were collected using a $1 \mathrm{~m}^{2}$ kick-net sampler [21] from wadable riffles $(<0.5 \mathrm{~m}$ deep) that were chosen randomly. At the end of the sampling period, 18 replicate benthic samples (i.e. six samples multiplied by 3 sampling occasions) had been collected from each of these reach sites. Sampling began at the downstream end of each 100-m reach and proceeded upstream. The collected organisms were emptied into white enamel trays for sorting by passing the samples through a 500- $\mu \mathrm{m}$ sieve. Large debris was removed after rinsing and inspecting, and then again inspecting the kick-net for organisms. The macroinvertebrate samples were transferred into pre-labeled high density polypropylene (HPDE) bottles and preserved in $80 \%$ ethanol and stored at $4{ }^{\circ} \mathrm{C}$. The samples were then transported to the Ecotoxicology Research Facility at Arkansas State University for identification and enumeration. Sorting and enumeration were done according to methods described by Barbour et al. [10]. The sorted organisms were placed into pre-labeled glass vials and later identified using taxonomic keys published by Merritt and Cummins [22]. Identification was limited to family- and in some instances genus- levels.

Stream habitat assessment was done using the qualitative habitat evaluation index (QHEI) method as described in the Ohio Environmental Protection Agency [23]. The variables considered in stream habitat assessment included epifaunal substrate, embeddedness, velocity/depth regime, sediment composition, channel flow, channel alteration, frequency of riffles, bank stability, vegetation cover, and riparian zone. Each of these variables was given a score between 0 and 100 , with values closer to 0 and 100 indicating poorest and best habitat quality, respectively. Measurements of several physical and chemical water and sediment quality variables were recorded for each site at the time of macroinvertebrate sampling (Table 2). The water and sediment quality measurements were done according to methods described in Ogendi et al. [17, 18]. Briefly, water samples were collected 


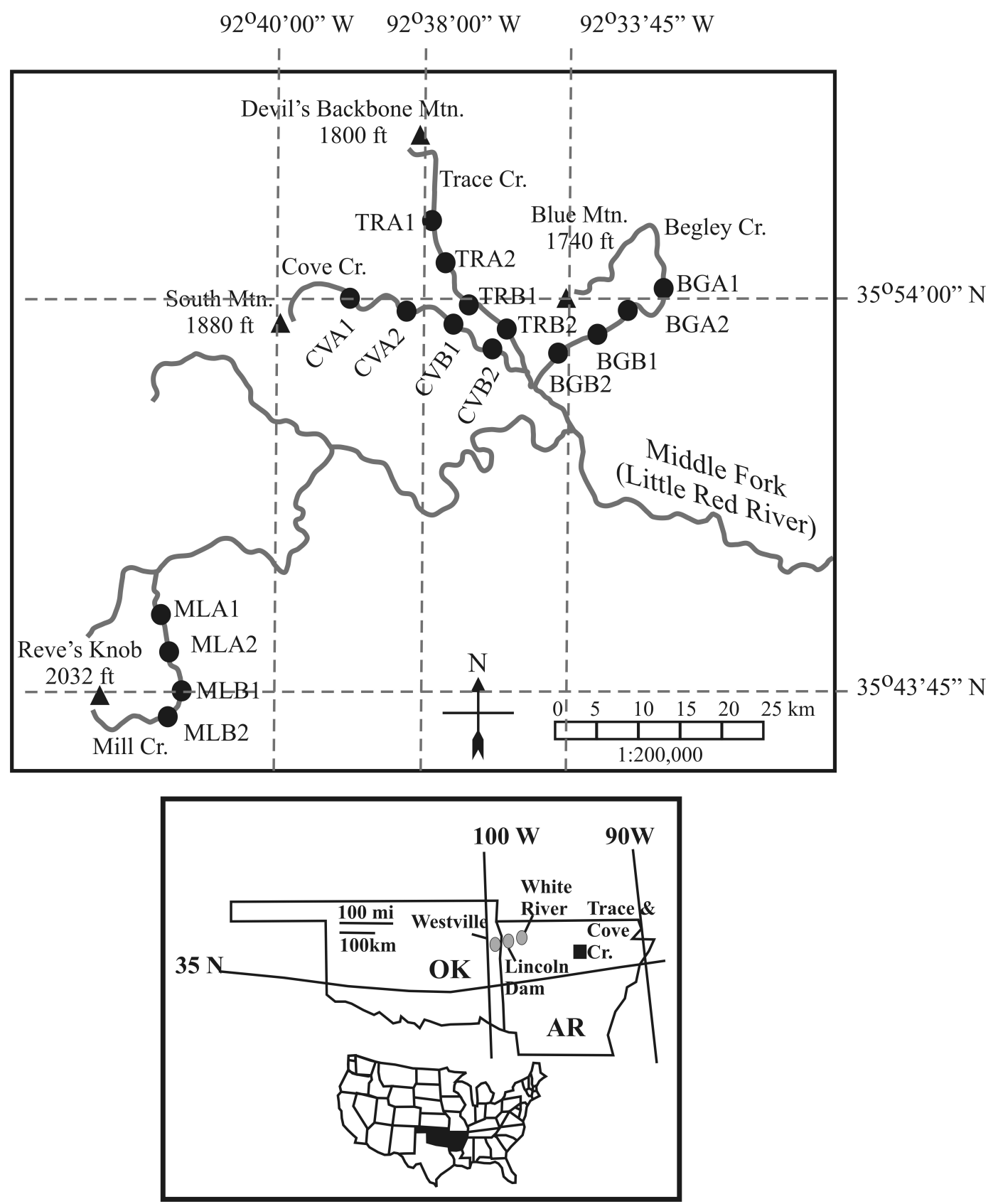

Fig. (1). Location of sampling sites (solid circles) on streams draining black shales (i.e. Trace, Begley, and Cove creeks), and on a limestonedraining stream (Mill Creek). Sampling sites coded TRA, TRB are located on Trace Creek; BGA, BGB on Begley Creek; CVA, CVB on Cove Creek; and MLA and MLB on Mill Creek. Numbers 1 and 2 after the codes represent sites within a sampling reach. The streams are part of the Little Red River watershed (Hydrologic Unit Code 11010014) in north-central Arkansas, USA.**

using trace-metal clean procedures [24, 25]. All equipment used for sample collection, storage and analysis of trace metals were pre-cleaned using high-purity nitric acid (GFS Chemicals Inc.) and thoroughly rinsed with Milli-Q water. The water samples were filtered immediately through 0.45 $\mu \mathrm{m}$ Gelman in-line filters and acidified with ultra-pure

**Fig. (1). is a modified version of material appearing in Developments in Environmental Science, Vol 5, by D. Sakar, D. Datta, R. Hannigan, Association of dissolved organic carbon with stream discharge and dissolved metals concentrations in black shale draining streams, p 247-272, 2007. Permission was granted from Elsevier.
$\mathrm{HNO}_{3}$ to $\mathrm{pH}<2$ and stored in polypropylene bottles at $4^{\circ} \mathrm{C}$ prior to trace metal analyses. Metal concentrations were determined by the Dynamic Reaction Cell Inductively Coupled Plasma Mass Spectrometry (DRC-ICP-MS; Elan 9000 PerkinElmer) following EPA 200.8 methodology. The trace metal concentrations were within $3 \%$ of the reported values for the standards.

\section{Sediment Collection and Metal Analysis}

Three composite sediment samples were collected from three depositional zones near each of the macroinvertebrate sampling sites. Each composite sample consisted of five 
sediment scoops collected from a single depositional area targeting the 0 to $5-\mathrm{cm}$ sediment depth. The samples were collected using a metal-free HDPE scoop and transferred to pre-cleaned and metal-free sample jars. The HDPE scoop was decontaminated between sample sites using Alconox. Sediment samples were stored at $4{ }^{\circ} \mathrm{C}$ and transported to the Water-Rock-Life Laboratory at Arkansas State University for analysis. Processing of sediments and analysis for metals were done according to methods described in Ogendi et al. [17]. Briefly, metals were determined by digesting $50 \mathrm{mg}$ of sediment sample in ultra-pure nitric acid $\left(\mathrm{HNO}_{3}\right)$ and hydrofluoric acid (HF) and brought to a final volume of $100 \mathrm{~mL}$ in $2 \%$ ultrapure $\mathrm{HNO}_{3}$. Metal concentrations in the sediments were measured using a DRC, Perkin Elmer ICP-MS. The EPA 6020 protocols were followed when analyzing metal contents in water samples.

\section{Statistical Analyses}

For each sampling occasion and site, mean macroinvertebrate metric scores and standard deviations were calculated using a pool of six kick net replicate samples. All data were tested for normality and homogeneous variance using Kolmogorov-Smirnov test ( $\mathrm{p}>0.15)$, and Levene's test ( $\mathrm{p}>$ 0.05 ), respectively. After analysis of residuals, data that did not meet the assumptions for ANOVA were log-transformed or square-root transformed prior to any statistical analyses. The transformations applied to the data with non-normal residuals achieved normality. Analysis of variance (ANOVA) was performed on macroinvertebrate metrics and metal concentrations data with streams, sites and sampling occasions as the main effects. Pearson Correlation Coefficients between environmental variables and macroinvertebrate abundance and richness metrics were calculated. In all statistical analyses, except where defined, the criterion for significance was a $p$-value of $\leq 0.05$.

\section{RESULTS}

\section{Water and Sediment Metal Concentrations}

The average concentrations of trace metals ( $\mathrm{As}, \mathrm{Ag}, \mathrm{Cd}$, $\mathrm{Cr}, \mathrm{Cu}, \mathrm{Ni}, \mathrm{Pb}, \mathrm{Zn})$ and major elements $(\mathrm{Fe}$ and $\mathrm{Mn})$ in sediments were significantly higher in Trace, Begley, and Cove Creeks (shale-draining streams) than those of Mill Creek (limestone-draining stream) $(\mathrm{p}<0.001$; Table 1). In Trace Creek sediments, Cr levels were up to 35 times higher than those of Mill Creek. The concentrations of Ni were over 100 times higher in Trace and Begley than in Mill Creek sediments. Concentrations of As in the shale-draining stream sediments were also significantly higher than those of Mill Creek ( $\mathrm{p}<0.05)$. On average, the concentrations of $\mathrm{Cd}, \mathrm{Cu}$, $\mathrm{Pb}$, and $\mathrm{Zn}$ in Trace and Begley Creek sediments were 18, 600,10 , and 300 times higher than those of Mill Creek (Table 1). Trace metal concentrations in Cove Creek sediments were significantly lower than those of Begley and Trace Creek sediments, but significantly higher than those of Mill Creek sediments $(\mathrm{p}<0.05)$. Sediment concentrations for $\mathrm{Fe}$ and $\mathrm{Mn}$ in Mill Creek samples were between two and three times lower than those of Trace, Begley and Cove Creeks. Variations in metal concentrations between samples collected from the same stream were not significant ( $p>0.05$; Table 1).

\section{Physical and Chemical Variables of Sediments and Water}

No significant differences in habitat scores were observed between streams $(\mathrm{F}=2.19 ; \mathrm{p}=0.23$; Table 1). All environmental variables considered in qualitative habitat assessment were similar for the shale- and limestonedraining streams. However, significant differences in particle size were observed among all sediments $(\mathrm{p}<0.05$; Table 1). Particle size analysis revealed that the sediments were dominated by sand which constituted between 54\% $( \pm 0.9)$ in Begley Creek and 72\% ( $( \pm 0.0 .9)$ in Mill Creek sediments. Percent silt varied between $27( \pm 0.6)$ in Mill Creek sediments and $35( \pm 0.9)$ in Begley sediments (Table 1). Clay constituted the least of the three particle sizes in all sediment samples from the four streams. Mill Creek sediments had a significantly lower amount of clay compared to that of Trace, Begley, and Cove creeks ( $\mathrm{p}<0.05$; Table, 1).

The average percent organic carbon (OC) in Trace, Begley, and Cove Creek sediments was significantly higher than that of Mill Creek ( $<<0.05$; Table 1). Organic carbon contents in Trace, Begley, and Cove Creek sediments were between three and seven times higher than those of Mill Creek (Table 1). However, no significant variations in OC contents were observed among the three sampling occasions at each site $(\mathrm{F}=1.78 ; \mathrm{p}>0.05)$. Additionally, no significant differences in temperature and dissolved oxygen were observed between sites or sampling occasions ( $p>0.05$; Table 1). The mean $\mathrm{pH}$ range was from $5.0 \pm 0.1$ (mean \pm standard deviation) to $7.0( \pm 0.2)$ for shale draining streams, whereas the average $\mathrm{pH}$ was $7.5( \pm 0.0 .2)$ for Mill Creek. Electrical conductivity for water samples collected from Trace, Begley, and Cove Creeks was significantly higher than that of Mill Creek ( $\mathrm{p}<0.05$; Table 1).

\section{Macroinvertebrate Abundance and Richness Metrics}

A total of between 14 to 18 macroinvertebrate orders (herein loosely termed taxa) were recorded in the four streams during the three sampling occasions. However, between 50 to $90 \%$ of the total benthic macroinvertebrate abundance and taxa richness was attributed to six taxa, which included Ephemeroptera, Plecoptera, Trichoptera, Coleoptera, Diptera, and Odonata (Table 2). The contribution of the six taxa was considerably higher in Mill Creek $(90 \%)$ than in Cove Creek (23\%), Begley Creek (31\%), and Trace Creek $(50 \%)$. On average, total macroinvertebrate abundance in Mill Creek was between three and seven times higher than that of Trace, Begley, and Cove Creeks (Table 2). Average total abundance of Ephemeroptera in Mill Creek was significantly higher than that of Trace, Begley, and Cove Creeks ( $p<0.05$; Table 2). However, no significant variations in total abundance of Ephemeroptera were observed between macroinvertebrate samples collected from sites located on the same stream $(p>0.05)$. Similar trends in total abundance were observed for the plecopteran, trichopteran, coleopteran, and Odonata taxa (Table 2). All sampling sites differed significantly in macroinvertebrate total abundance over the three sampling occasions $(\mathrm{p}<0.05)$ in which samples collected in October 2003, and July 2005 had the lowest and highest total abundance, respectively. Trichoptera and Diptera (chironomids) had the least contribution to the 
Table 1. Mean \pm SD (SD: Standard Deviation) of Sediment Metal Concentrations and other Physical and Chemical Parameters at Each Sampled Site in Trace (TRA, TRB), Begley (BGA, BGB), Cove (CVA, CVB), and Mill (MLA, MLB) Creeks (AR, USA)

\begin{tabular}{|c|c|c|c|c|c|c|c|c|c|c|}
\hline Variable & TRA & TRB & BGA & BGB & CVA & CVB & MLA & MLB & F-Value & $p$-Value \\
\hline $\mathrm{Cr}(\mathrm{ppm})$ & $60 \pm 8.0 \mathrm{a}$ & $65 \pm 12.5 \mathrm{a}$ & $56 \pm 6.4 \mathrm{a}$ & $55 \pm 6.1 \mathrm{a}$ & $4.7 \pm 0.2 b$ & $5.7 \pm 0.3 b$ & $1.7 \pm 0.1 \mathrm{c}$ & $1.6 \pm 0.2 \mathrm{c}$ & 71.1 & 0.001 \\
\hline $\mathrm{Cu}(\mathrm{ppm})$ & $60 \pm 5.1 \mathrm{a}$ & $64 \pm 10.4 \mathrm{a}$ & $55 \pm 3.8 \mathrm{a}$ & $54 \pm 2.4 \mathrm{a}$ & $11.1 \pm 2.1 \mathrm{~b}$ & $2.2 \pm 0.8 \mathrm{~b}$ & $0.1 \pm 0.0 \mathrm{c}$ & $0.1 \pm 0.0 \mathrm{c}$ & 145.2 & 0.001 \\
\hline $\mathrm{Zn}(\mathrm{ppm})$ & $334 \pm 27 \mathrm{a}$ & $341 \pm 62 \mathrm{a}$ & $312 \pm 42 \mathrm{a}$ & $385 \pm 81 \mathrm{a}$ & $104 \pm 11.2 b$ & $174 \pm 48 b$ & $1.1 \pm 14 \mathrm{c}$ & $0.8 \pm 0.0 \mathrm{c}$ & 60.9 & 0.001 \\
\hline $\mathrm{Ag}(\mathrm{ppm})$ & $0.7 \pm 0.1 \mathrm{a}$ & $0.8 \pm 0.1 \mathrm{a}$ & $0.5 \pm 0.2 \mathrm{a}$ & $0.4 \pm 0.2 \mathrm{a}$ & $0.6 \pm 0.4 \mathrm{~b}$ & $0.5 \pm 0.1 \mathrm{a}$ & $0.2 \pm 0.1 \mathrm{~b}$ & $0.2 \pm 0.1 \mathrm{~b}$ & 9.7 & 0.001 \\
\hline $\mathrm{Cd}(\mathrm{ppm})$ & $4.4 \pm 0.3 \mathrm{a}$ & $4.4 \pm 0.3 \mathrm{a}$ & $4.2 \pm 0.6 \mathrm{a}$ & $5.3 \pm 1.4 \mathrm{a}$ & $0.5 \pm 0.1 \mathrm{~b}$ & $1.2 \pm 0.5 \mathrm{~b}$ & $0.3 \pm 0.2 b$ & $0.2 \pm 0.1 \mathrm{~b}$ & 32.7 & 0.001 \\
\hline $\mathrm{Pb}(\mathrm{ppm})$ & $1.2 \pm 0.1 \mathrm{a}$ & $1.1 \pm 0.3 \mathrm{a}$ & $0.5 \pm 0.2 \mathrm{~b}$ & $0.5 \pm 0.3 \mathrm{~b}$ & $0.2 \pm 0.1 \mathrm{~b}$ & $0.3 \pm 0.2 b$ & $0.1 \pm 0.0 \mathrm{c}$ & $0.1 \pm 0.0 \mathrm{c}$ & 23.4 & 0.001 \\
\hline $\mathrm{Fe}(\mathrm{ppm})$ & $1428 \pm 484 \mathrm{a}$ & $1527 \pm 651 \mathrm{a}$ & $1281 \pm 210 \mathrm{a}$ & $1263 \pm 182 \mathrm{a}$ & $783 \pm 80 b$ & $815 \pm 134 b$ & $480 \pm 21 \mathrm{c}$ & $454 \pm 54 \mathrm{c}$ & 5.70 & 0.001 \\
\hline Temp. $\left({ }^{\circ} \mathrm{C}\right)$ & $19.3 \pm 3.2 \mathrm{a}$ & $19.3 \pm 4.0 \mathrm{a}$ & $20 \pm 3.8 \mathrm{a}$ & $19.3 \pm 3.2 \mathrm{a}$ & $20 \pm 2.6 \mathrm{a}$ & $20.2 \pm 3.6 \mathrm{a}$ & $19.3 \pm 3.2 \mathrm{a}$ & $21 \pm 3.5 \mathrm{a}$ & 0.1 & 0.251 \\
\hline $0.7 \mathrm{a} 6$. & $6.5 \pm 0.6 \mathrm{a}$ & $5.8 \pm 0.3 \mathrm{a}$ & $6.1 \pm 1.1 \mathrm{a}$ & $6.5 \pm 1.1 \mathrm{a}$ & $5.8 \pm 1.0 \mathrm{a}$ & $5.9 \pm 1.0 \mathrm{a}$ & $6.9 \pm 0.7 \mathrm{a}$ & $6.7 \pm 0.5 \mathrm{a}$ & 0.9 & 0.178 \\
\hline $\mathrm{pH}$ & $5.3 \pm 0.5 \mathrm{a}$ & $5.0 \pm 0.4 \mathrm{a}$ & $5.0 \pm 0.1 \mathrm{a}$ & $5.0 \pm 0.3 \mathrm{a}$ & $7.0 \pm 0.2 b$ & $7.0 \pm 0.2 b$ & $7.5 \pm 0.1 b$ & $7.5 \pm 0.2 b$ & 57.1 & 0.001 \\
\hline $\mathrm{CD}(\mu \mathrm{S} / \mathrm{cm})$ & $186 \pm 11 \mathrm{a}$ & $180 \pm 12 \mathrm{a}$ & $179 \pm 6.1 \mathrm{a}$ & $180 \pm 12 \mathrm{a}$ & $146 \pm 7.0 \mathrm{~b}$ & $143 \pm 8.1 b$ & $114 \pm 5.9 \mathrm{c}$ & $119 \pm 5.1 \mathrm{c}$ & 33.4 & 0.001 \\
\hline Habitat Score & $87.5 \pm 7.5 \mathrm{a}$ & $86.5 \pm 8.8 \mathrm{a}$ & $87.5 \pm 5.9 \mathrm{a}$ & $87.5 \pm 8.2 \mathrm{a}$ & $87.0 \pm 8.6 \mathrm{a}$ & $86.0 \pm 8.4 \mathrm{a}$ & $88.0 \pm 4.8 \mathrm{a}$ & $87.5 \pm 5.9 \mathrm{a}$ & 0.8 & 0.001 \\
\hline $\operatorname{Sand}(\%)$ & $61 \pm 0.8 \mathrm{a}$ & $62 \pm 0.9 \mathrm{a}$ & $56 \pm 1.1 \mathrm{~b}$ & $54 \pm 0.9 \mathrm{~b}$ & $66 \pm 0.7 \mathrm{c}$ & $67 \pm 0.8 \mathrm{c}$ & $71 \pm 1.0 \mathrm{~d}$ & $70 \pm 1.0 \mathrm{~d}$ & 56.8 & 0.001 \\
\hline Silt (\%) & $31 \pm 0.9 \mathrm{a}$ & $29 \pm 0.8 \mathrm{a}$ & $34 \pm 0.9 b$ & $34 \pm 1.3 b$ & $28 \pm 1.1 \mathrm{a}$ & $27 \pm 0.3 \mathrm{a}$ & $29 \pm 0.6 \mathrm{a}$ & $27 \pm 0.6 \mathrm{a}$ & 41.3 & 0.001 \\
\hline Clay $(\%)$ & $8.2 \pm 0.4 \mathrm{a}$ & $8.6 \pm 0.5 \mathrm{a}$ & $9.7 \pm 0.6 b$ & $9.2 \pm 0.4 \mathrm{~b}$ & $5.9 \pm 0.3 \mathrm{c}$ & $6.0 \pm 0.5 \mathrm{c}$ & $0.9 \pm 0.1 \mathrm{~d}$ & $1.1 \pm 0.2 \mathrm{~d}$ & 28.7 & 0.001 \\
\hline
\end{tabular}

OC: Organic Crbon; DO: Dissolved Oxygen; CD: Conductivity; " $a b c d$ " notation: all sites labeled with same letter are not significantly different ( $p>0.05)$. ppm stands for parts per million.

Table 2. Mean \pm SD (SD: Standard Deviation) Macroinvertebrate Abundance in Trace (TRA, TRB), Begley (BGA, BGB), Cove (CVA, CVB), and Mill (MLA, MLB) Creeks (AR, USA)

\begin{tabular}{|c|c|c|c|c|c|c|c|c|c|}
\hline \multicolumn{9}{|c|}{ Macroinvertebrate Taxa } \\
\hline Sites & EP & PL & TR & CL & CH & Non-CH & OD & OT & TA \\
\hline \hline TRA & $32 \pm 12 \mathrm{~A}$ & $2 \pm 1.0 \mathrm{~A}$ & $0 \pm 0 \mathrm{~A}$ & $42 \pm 12 \mathrm{~A}$ & $22 \pm 8 \mathrm{~A}$ & $11 \pm 3 \mathrm{~A}$ & $37 \pm 11 \mathrm{~A}$ & $130 \pm 73 \mathrm{~A}$ & $276 \pm 147 \mathrm{~A}$ \\
\hline TRB & $33 \pm 12 \mathrm{~A}$ & $0.3 \pm 0.1 \mathrm{~A}$ & $0 \pm 0 \mathrm{~A}$ & $55 \pm 14 \mathrm{~A}$ & $27 \pm 8 \mathrm{~A}$ & $10 \pm 4 \mathrm{~A}$ & $31 \pm 11 \mathrm{~A}$ & $197 \pm 131 \mathrm{~B}$ & $352 \pm 204 \mathrm{~B}$ \\
\hline BGA & $67 \pm 24 \mathrm{~A}$ & $1 \pm 0.5 \mathrm{~A}$ & $0 \pm 0 \mathrm{~A}$ & $57 \pm 16 \mathrm{~A}$ & $19 \pm 9 \mathrm{~A}$ & $17 \pm 5 \mathrm{~A}$ & $84 \pm 25 \mathrm{~A}$ & $126 \pm 70 \mathrm{~A}$ & $371 \pm 192 \mathrm{~B}$ \\
\hline BGB & $71 \pm 29 \mathrm{~A}$ & $4 \pm 1 \mathrm{~A}$ & $1 \pm 0.7 \mathrm{~A}$ & $60 \pm 22 \mathrm{~A}$ & $23 \pm 10 \mathrm{~A}$ & $23 \pm 9 \mathrm{~A}$ & $50 \pm 19 \mathrm{~A}$ & $91 \pm 71 \mathrm{C}$ & $323 \pm 221 \mathrm{~B}$ \\
\hline CVA & $168 \pm 56 \mathrm{~B}$ & $27 \pm 8 \mathrm{~B}$ & $4 \pm 1.2 \mathrm{~A}$ & $82 \pm 25 \mathrm{~A}$ & $16 \pm 11 \mathrm{~A}$ & $12 \pm 4 \mathrm{~A}$ & $104 \pm 29 \mathrm{~B}$ & $58 \pm 38 \mathrm{C}$ & $466 \pm 240 \mathrm{C}$ \\
\hline CVB & $181 \pm 50 \mathrm{~B}$ & $54 \pm 17 \mathrm{~B}$ & $9 \pm 3.0 \mathrm{~B}$ & $126 \pm 35 \mathrm{~B}$ & $19 \pm 10 \mathrm{~A}$ & $18 \pm 7 \mathrm{~A}$ & $164 \pm 55 \mathrm{~B}$ & $98 \pm 75 \mathrm{C}$ & $671 \pm 338 \mathrm{C}$ \\
\hline MLA & $473 \pm 129 \mathrm{C}$ & $211 \pm 49 \mathrm{C}$ & $28 \pm 6.0 \mathrm{C}$ & $190 \pm 49 \mathrm{C}$ & $16 \pm 12 \mathrm{~A}$ & $33.0 \pm 9 \mathrm{~B}$ & $246 \pm 56 \mathrm{C}$ & $160 \pm 86 \mathrm{D}$ & $1357 \pm 602 \mathrm{D}$ \\
\hline MLB & $491 \pm 135 \mathrm{C}$ & $354 \pm 87 \mathrm{C}$ & $26 \pm 6.0 \mathrm{C}$ & $197 \pm 57 \mathrm{C}$ & $17 \pm 12 \mathrm{~A}$ & $32 \pm 10 \mathrm{~B}$ & $260 \pm 63 \mathrm{C}$ & $153 \pm 90 \mathrm{D}$ & $1529 \pm 700 \mathrm{D}$ \\
\hline$F$-value & 110.5 & 98.5 & 17.2 & 68.7 & 0.7 & 16.3 & 56.9 & 29.6 & 34.5 \\
\hline$p$-value & 0.001 & 0.001 & 0.002 & 0.001 & 0.681 & 0.008 & 0.001 & 0.002 & 0.005 \\
\hline
\end{tabular}

EP: Ephemeroptera; PL: Plecoptera; TR: Trichoptera; CL: Coleoptera; CH: Chironomids; Non-CH: Non-Chironomids; OD: Odonata; OT: Others; and TA: Total Abundance. " $a b c d$ " notation: all sites labeled with same letter are not significantly different $(p>0.05)$. 
total macroinvertebrate abundance in shale-draining and limestone-draining streams, respectively (Table 2 ).

Collectively, dipterans (chironomids and non-chironomids) accounted for an average of 2 to $10 \%$ of the total macroinvertebrate abundance in shale-draining streams, whereas their contribution in Mill Creek benthic samples was $<2 \%$. On average, the total abundance of chironomids in shaledraining streams did not differ significantly from that of Mill Creek ( $>$ > 0.05; Table 2).

Total taxa richness was significantly higher in Mill Creek macroinvertebrate samples than that of Trace, Begley, and Cove Creeks ( $p<0.001$; Table 3). The dominant taxa in both shale-draining and limestone-draining streams were Ephemeroptera, Coleoptera, and Odonata (Table 3). The contribution of Ephemeroptera-Plecoptera-Trichoptera (EPT) to total benthic macroinvertebrate abundance ranged from 9 to $22 \%$ for Trace and Begley Creeks, whereas it ranged from 50 to $60 \%$ for Mill Creek ( $p>0.05$; Table 3). Among EPT taxa, Ephemeroptera had the highest percentage contribution to the total macroinvertebrate richness. No significant differences in \% EPT were observed between sampling occasions. Ephemeoptera, Plecoptera, Coleoptera and EPT richness in limestone-draining Mill Creek were significantly higher than those of shale-draining streams $(p<0.001$; Table 3). Percent EPT and EPT taxa richness in Cove Creek were significantly higher compared with those of Begley and Trace Creeks ( $\mathrm{p}<$ 0.001). Nonetheless, both metrics were significantly lower for Cove Creek samples compared with those of Mill Creek (Table 3).

\section{Correlations between Metals and Macroinvertebrate Metrics}

As expected, significantly negative correlations were observed between richness metrics for Ephemeroptera, Ple- coptera, Trichoptera, taxa, and EPT and sediment trace metals concentrations ( $\mathrm{Ni}, \mathrm{Cr}, \mathrm{Cd}, \mathrm{Cu}, \mathrm{Zn}, \mathrm{As}, \mathrm{Pb}$ ) with Pearson's Correlation Coefficients ranging from 0.64 to 0.91 ( $p<$ 0.01 ; Table 4).

Conversely, positive correlations were observed between chironomids, non-chironomids, and Odonata and sediment metals concentrations with Pearson's Correlation Coefficients (PCC) ranging from 0.57 to 0.80 (Table 4). Significantly positive correlations were measured between $\mathrm{pH}$ and Ephemeroptera richness, Plecoptera richness, Trichoptera richness, Coleoptera richness, taxa richness, and EPT richness. Positive correlations were also measured between sediment metal concentrations and chironomids, non-chironomids, and Odonata. Conductivity-macroinvertebrate metric correlations were similar to those between sediment metals and macroinvertebrate metrics. Finally, insignificant correlations were observed between dissolved oxygen and sediment metal concentrations ( $p>0.05$; Table 4). Metal concentrations in sediments accounted for $72 \%$ of the total variation in macroinvertebrate metrics $(\mathrm{F}=53.9, \mathrm{p}<0.001)$, whereas $16 \%$ of the total variation observed in macroinvertebrate metrics between sites was explained by the amount of organic carbon and \% clay in the sediments.

\section{DISCUSSION}

\section{Metal Concentrations in Water and Sediments}

Results of metal concentrations in water samples collected from the study sites are published in Ogendi et al. [18]. As anticipated, shale sediment metal concentrations were higher than those of limestone sediments given the geologic composition of their respective watersheds. Studies on black shale weathering have demonstrated that black shalederived sediments and water contain elevated levels of metals including $\mathrm{As}, \mathrm{Cd}, \mathrm{Cr}, \mathrm{Cu}, \mathrm{Mo}, \mathrm{Pb}, \mathrm{Se}$, and $\mathrm{Zn}[13,15,17-$

Table 3. Mean \pm SD (SD: Standard Deviation) for Ecological Parameters at Various Sampling Sites in Trace, Begley, Cove, and Mill Creeks (AR, USA)

\begin{tabular}{|c|c|c|c|c|c|c|}
\hline \multicolumn{7}{|c|}{ Macroivertebrate Metrics } \\
\hline Sites & Taxa Richness & \% EPT & Ephem. Richness & Pleco. Richness & Cole. Richness & EPT Richness \\
\hline \hline TRA & $26.3 \pm 3.2 \mathrm{~A}$ & $11.6 \pm 3.9 \mathrm{~A}$ & $4.0 \pm 1.7 \mathrm{~A}$ & $2.0 \pm 1.7 \mathrm{~A}$ & $5.6 \pm 0.5 \mathrm{~A}$ & $6.0 \pm 3.0 \mathrm{~A}$ \\
\hline TRB & $25.0 \pm 3.5 \mathrm{~A}$ & $9.3 \pm 4.3 \mathrm{~A}$ & $4.3 \pm 1.2 \mathrm{~A}$ & $1.7 \pm 1.2 \mathrm{~A}$ & $5.7 \pm 1.6 \mathrm{~A}$ & $5.6 \pm 1.5 \mathrm{~A}$ \\
\hline BGA & $23.8 \pm 2.9 \mathrm{~A}$ & $17.3 \pm 4.4 \mathrm{~A}$ & $5.3 \pm 0.6 \mathrm{~A}$ & $1.6 \pm 2.1 \mathrm{~A}$ & $5.5 \pm 1.2 \mathrm{~A}$ & $7.0 \pm 1.7 \mathrm{~A}$ \\
\hline BGB & $25.3 \pm 3.2 \mathrm{~A}$ & $22.3 \pm 4.4 \mathrm{~A}$ & $5.0 \pm 1.4 \mathrm{~A}$ & $1.7 \pm 1.2 \mathrm{~A}$ & $5.6 \pm 1.7 \mathrm{~A}$ & $6.7 \pm 2.1 \mathrm{~A}$ \\
\hline CVA & $36.0 \pm 6.6 \mathrm{~B}$ & $42.4 \pm 5.6 \mathrm{~B}$ & $7.0 \pm 1.8 \mathrm{~A}$ & $3.7 \pm 0.5 \mathrm{~A}$ & $7.3 \pm 1.9 \mathrm{~A}$ & $11.7 \pm 1.7 \mathrm{~B}$ \\
\hline CVB & $36.3 \pm 6.8 \mathrm{~B}$ & $37.7 \pm 6.5 \mathrm{~B}$ & $7.3 \pm 1.5 \mathrm{~B}$ & $4.3 \pm 0.7 \mathrm{~A}$ & $7.0 \pm 1.2 \mathrm{~A}$ & $12.0 \pm 1.9 \mathrm{~B}$ \\
\hline MLA & $40.7 \pm 5.5 \mathrm{C}$ & $52.3 \pm 1.5 \mathrm{C}$ & $9.3 \pm 1.6 \mathrm{C}$ & $6.0 \pm 1.5 \mathrm{~B}$ & $8.1 \pm 1.9 \mathrm{~B}$ & $17.3 \pm 1.8 \mathrm{C}$ \\
\hline MLB & $42.0 \pm 6.0 \mathrm{C}$ & $57.1 \pm 1.7 \mathrm{C}$ & $9.0 \pm 1.9 \mathrm{C}$ & $6.2 \pm 1.3 \mathrm{~B}$ & $8.0 \pm 1.3 \mathrm{~B}$ & $17.0 \pm 2.3 \mathrm{C}$ \\
\hline F-value & 22.8 & 17.2 & 7.2 & 4.5 & 6.005 & 0.051 \\
\hline$p$-value & 0.001 & 0.001 & 0.006 & 13.8 & 0.001 \\
\hline
\end{tabular}

Means followed by the same uppercase letter are not significantly different; least significant difference $p<0.05$. EPT $=$ Ephemeroptera + Plecoptera + Trichoptera; Pleco. $=$ Plecoptera; Ephem. $=$ Ephemeroptera; Cole.$=$ Coleoptera. " $A B C$ " notation: all sites labeled with same letter are not significantly different $(p>0.05)$. 
Table 4. Pearson's Correlation Coefficients between Macroinvertebrate Metrics and Chemical and Physical Data at Trace, Begley, Cove and Mill Creeks (AR, USA)

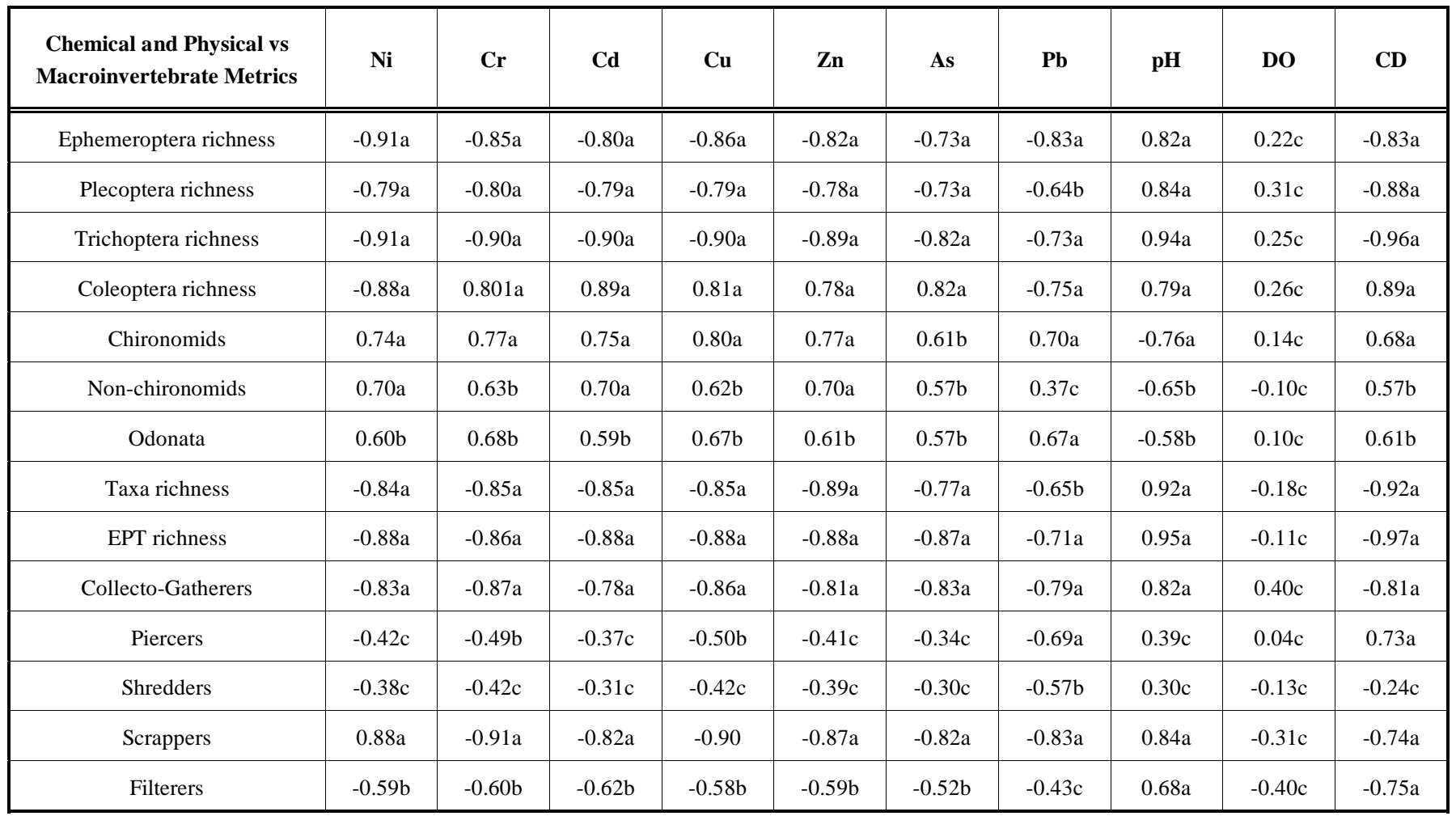

DO: Dissolved Oxygen; CD: Conductivity; a: coefficient is significant at $\mathrm{p}<0.001$; $\mathrm{b}$ : coefficient is significant at $\mathrm{p}=0.01$ to $0.049 ; \mathrm{c}$ : coefficient is significant at $\mathrm{p}=0.05$ to 0.1 .

18]. Chemical weathering of black shales releases metals, which have been shown to be transported during stormflow into adjacent aquatic ecosystems [15]. Significantly higher sediment extractable metals (SEM) have been observed in shale- than limestone-sediments [17]. The SEM fraction of the metals represents their molar concentrations that are toxicologically important. Only two samples in Begley Creek had measurable Acid volatile acid (AVS) [17] at one sampling occasion. All of the sediments contained SEM in excess of the AVS and thereby likely to be toxic to benthic organisms. Acid volatile sulfides (AVS) have been shown to bind metals in sediments thereby reducing potential toxicity to aquatic organisms $[26,27]$. In this study, the average oxygen levels were similar for all sites and during the three sampling occasions. Sufficient amounts of oxygen may indirectly influence metal concentrations by oxidizing AVS in sediments. Positive correlations between metal concentrations and clay and organic carbon contents were observed for the shale sediments. Adsorption of metals in sediments is positively correlated with organic carbon and clay contents. The observed low abundance and taxa richness in shaledraining streams may also in part be attributed to elevated metal concentrations in sediments. The concentrations of $\mathrm{Ni}$, $\mathrm{Cu}$, and $\mathrm{Cd}$ in Trace, Begley, and Cove Creek sediments exceeded effect range-low (ERL) values, and in some cases higher than effect range-medium (ERM) values that are outlined in the Sediment Quality Guidelines (SQGs) developed by NOAA [28]. Conversely, the concentrations of these metals in Mill Creek sediments were lower than the ERL and ERM values in the SQGs.

\section{Macroinvertebrate Metric Responses}

The characterized benthic macroinvertebrate communities in shale draining streams were consistent with described macroinvertebrate communities reported from metalimpacted streams $[5,6,8,9]$. The most common observation of metal contamination from both laboratory and field studies is a reduced abundance and taxa richness of metalsensitive ephemeropterans [1, 29-31]. Low Ephemeroptera density and/ or taxa richness have been used widely as sensitive and reliable indicators of impacts of metals on benthic macroinvertebrate communities in aquatic ecosystems [8, 9, 31]. In this study, Ephemeroptera density and taxa richness were highest in the least metal-contaminated Mill Creek, and lowest in Trace and Begley Creeks that contained elevated concentrations of potentially toxic metals. This assertion was supported by the strong and significantly negative correlations observed between sediment metal concentrations and EPT taxa richness and \% EPT. As indicated in the previous section, SEM exceeded AVS in all shale sediments hence the potential of being toxic to benthic communities. The Ephemeroptera families present in the four streams included Heptageniidae (genera: Stenonema, and Stenacron), Leptophlebiidae (Leptophlebia, and Chloroterpes), Caenidae (Caenis), and Baetidae (Procloeon, and Acentrella). The mayflies Stenacron, stenonema and Leptophlebia were the most common taxa observed in Mill Creek sites. Heptageniids were encountered rarely in the shale-draining streams compared to Mill Creek where they were abundant. There is no study to the best of our knowledge that documents macroinvertebrate assemblages and their responses to elevated metal 
levels in shale-draining streams. However, findings from metal pollution from anthropogenic activities (e.g. mining) and their impacts on macroinvertebrates show that taxa from the family Heptagenidae are relatively more sensitive to metal contamination than other families in the Ephemeroptera order [30]. Their absence from the shale-draining streams may have been caused in part by elevated metal levels in these streams. The dominant ephemeropteran family in shale-draining streams was Baetidae (genera: Acentrella and Procloeon). High abundance of baetids may be explained by their ability to tolerate metals compared with other ephemeropteran taxa. Some species of the genus Baetis have been shown to be metal-tolerant [32].

Another observation on the macroinvertebrate assemblages of the shale-draining streams consistent with metals effects on macroinvertebrate communities was low Plecoptera and Trichoptera abundance. Similar observations on the two macroinvertebrate taxa were reported by Clements et al. [33] and Beltman et al. [4]. Studies by Plafkin et al. [34] and Barbour et al. [35] found Ephemeroptera, Plecoptera, and Trichoptera richness to be sensitive variables to a variety of stressors including metal contaminants. The principal Plecoptera families in the four streams included Perlidae (Perlinella), Perlolidae (Isoperla, and Calliperla), Chloroperlidae (Sweltsa), and Leuctridae (Zealeuctra). However, no Chloroperlids or Leuctrids were encountered in Trace and Begley Creeks. This result is also consistent with metal effects on the two macroinvertebrate taxa reported by Clements [8] and Clements and Kiffney [9]. Absence of these metal-sensitive taxa may be attributed to the elevated metal concentrations as shown by the associated negative correlations between metals and the plecoptera richness metrics (Table 4). The chloroperlids in particular have been found to be sensitive to metal contamination, and therefore easily eliminated by elevated metal concentrations in streams [9]. The order Trichoptera was represented by Glossosomatidae (genus: Agapetus) and Rhyacophiliidae (Rhyacophila) families with relatively higher densities in Mill Creek than those of shaledraining streams. The total number of taxa in Mill Creek was one and one-half times more than that of shale-draining streams. Similar observations on taxa richness in streams with elevated metal levels have been made by Clements [36], Selby et al. [37], and Kilgour et al. [32].

Lower Coleoptera abundance and taxa richness were also observed in shale-draining streams compared with those of Mill Creek sites. The dominant coleopteran families included Psephenidae (genus: Psephenus), Hydrophilidae (Berosus, and Tropisternus), Elmidae (Stenelmis and Optioservus) and Microsporidae (Sphaerius). Despite the differences in Coleoptera total density and taxa richness, the genus Psephenus exhibited no significant differences between sites. This result is not consistent with metals effects on Psephenus spp. found elsewhere. For instance, Winner et al. [38] found that Psephenus spp. was the most sensitive taxon to $\mathrm{Cu}$ dosing of a stream. The concentration of copper in shale-draining stream sediments ranged from 54 to $64 \mathrm{mg} / \mathrm{kg}$. This $\mathrm{Cu}$ concentration was expected to have harmful effects on metal-sensitive species including Psephenus spp. One plausible speculation for this observation may be that Psephenus developed tolerance to metals in shale-draining streams. Another possibility is that the observed high $\mathrm{pH}$ at the shale streams may have prevented mobilization of metals so that they were less (bio) available. A study by Specht et al. [11] found that under high $\mathrm{pH}$ conditions, coleopteran Psephenus herricki may be metal tolerant and actually increased in abundance downstream from mining sites.

The abundance of the genus Optioservus was also significantly higher in shale-draining streams compared with that of the limestone-draining stream. Optioservus is known to be relatively sensitive to metals contamination and petrochemical pollutants [39]. Chadwick et al. [40] also found low densities of Optioservus downstream from a mine input to a Rocky Mountain stream. Our findings are also contrary to those of Beltman et al. [4] who observed that early instars of Optioservus spp. may be adversely affected by $\mathrm{Cu}$ concentrations as low as $5 \mu \mathrm{g} / \mathrm{L}$. Copper concentrations in shaledraining streams were several orders of magnitude compared to those observed in the two studies. The observed high abundance of metal-sensitive communities in metal impacted streams can probably be associated with metal tolerance of the macroinvertebrates as well as existing environmental variables (high dissolved organic carbon, dissolved oxygen and $\mathrm{pH}$ ) that could have reduced metal bioavailability. The relatively high carbon and clay concentrations in the system would sequester metals in the shale sediments. Certain macroinvertebrate taxa may have developed tolerance to metals after a long exposure to elevated metal levels. Presence of metal-sensitive taxa in shale-draining streams may also be attributed to drift from unaffected sites. Macroinvertebrate drift contributes significantly to recolonization of disturbed stream sites [12]. Beltman et al. [4] further observed that drift from undisturbed sites significantly influenced community structure of macroinvertebrates in disturbed systems. However, in this study macroinvertebrate drift was less likely because all streams surrounding the sampling sites drain the Mississippian Fayetteville Shale.

The total macroinvertebrate abundance metric was sensitive to higher metal concentrations in the shale-draining streams. Approximately $90 \%$ of the total variation in macroinvertebrate total abundance was explained by metal concentrations in sediments. This is contrary to observations from other studies. Macroinvertebrate abundance metrics have been shown to be highly variable and thus, lack sensitivity to ecosystem disturbance [41]. The low benthic macroinvertebrate density in shale-draining streams is consistent with those from related studies in which total abundances of macroinvertebrate communities are low in metal-contaminated streams $[1,31,40]$. Except for the Dipterans, densities of all other macroinvertebrate taxa were lower in shaledraining streams compared with those of the limestonedraining stream. The relatively high Dipteran abundance in shale-draining streams may be attributed to their ability to tolerate high metal concentrations [8].

\section{CONCLUSIONS}

As expected, sediments collected from shale-draining streams contained high metal concentrations compared with those of the limestone-draining stream. The observed low macroinvertebrate abundance and taxa richness in the shaledraining streams was partly attributed to elevated metal concentrations. Elevated concentrations of metals in shale stream sediments may have caused mortality and reduction in growth of metal-sensitive taxa. A laboratory sediment 
toxicity study by Ogendi et al. [17] using midge larvae demonstrated that their reduced growth and survival was caused by elevated metal concentrations in sediments collected from the study sites. Changes in macroinvertebrate assemblages associated with elevated metal levels appear to operate through the progressive selection against the least metaltolerant to the most metal-tolerant taxa within the community. Local extinctions of sensitive species is the most obvious way that metal exposure has manifested itself in community-level attributes. The absence of certain species of metal-sensitive Heptageniids, Chloroperlids and Leuctrids at sites located on shale-draining streams where metal levels were highest was an indication of where metal-specific effects were most pronounced.

This study further found that richness metrics were the most sensitive to elevated metals in shale-draining streams and therefore suitable for biomonitoring purposes of such streams. The sensitivity of richness metrics to elevated metal concentrations demonstrated that the overall effects observed at the community level result from metal effects at the individual and population levels. Measuring metals concentrations in sediments coupled with sediment toxicity bioassays, habitat assessments and macroinvertebrate community surveys, provided us with a better understanding of macroinvertebrate assemblages, and the impacts of metals on the macroinvertebrate communities in shale streams. Continuing such measurements, coupled with more detailed studies on the geochemistry of metals, macroinvertebrate metal bioaccumulation, and macroinvertebrate ecology, would advance our understanding of macroinvertebrate assemblages in streams with elevated metal levels. Data on the spatial and temporal macroinvertebrate assemblages forms the basis upon which sound state and federal government policies are made with regard to land development in areas underlain by black shales as well as aquatic species management and conservation.

\section{ACKNOWLEDGEMENTS}

This study was made possible through a grant from the National Science Foundation (EAR 0233661 - Hannigan and Farris). We appreciate the assistance offered by Dr. Aboubakar Sako and Danielle Smith during water, sediment and macroinvertebrate samples collection. The authors are also greatly indebted to Dr. Sam McCord for his assistance in macroinvertebrate taxonomy. We are greatly indebted to Dr. Yingtao Chai for his technical support during trace metal analysis on the direct reaction cell inductively coupled plasma-mass spectrophotometer (DRC ICP-MS). Finally, we acknowledge Dr. Steve Coghlan for his constructive criticism of an earlier version of this manuscript, and two anonymous reviewers for their critiques and comments that significantly improved this manuscript.

\section{REFERENCES}

[1] Winner RW, Boesel MW, Farrel MP. Insect community structure as an index of heavy-metal pollution in lotic ecosystems. Can J Fish Aquat Sci 1980; 37: 647-55.

[2] Clements WH, Cherry DS, Van Hassel JH. Assessment of the impact of heavy metals on benthic communities at the Clinch River (Virginia): Evaluation of an index community sensitivity. Can J Fish Aquat Sci 1992; 49: 1686-94.
[3] Clements WH, Carlisle DM, Courtney LA, Harrahy EA. Integrating observational and experimental approaches to demonstrate causation in stream biomonitoring studies. Environ Toxicol Chem 2002; $21: 1138-46$.

[4] Beltman DJ, Clements WH, Lipton J, Cacela D. Benthic invertebrate metals exposure, accumulation, and community-level effects downstream from a hard-rock mine site. Environ Toxicol Chem 1999; 18: 299-307.

[5] Cain DJ, Luoma SN, Wallace WG. Linking metal bioaccumulation of aquatic insects to their distribution patterns in a mining-impacted river. Environ Toxicol Chem 2004; 23:1463-73.

[6] Griffith MB, Lazorchak JM, Herlihy AT. Relationships among exceedences of metals criteria, the results of ambient bioassays, and community metrics in mining-impacted streams. Environ Toxicol Chem 2004; 23: 1786-95.

[7] Cain DJ, Luoma SN. Metal exposures to native populations of the caddisfly Hydropsyche (Trichoptera: Hydropsychidae) determined from cystolic and whole body metal concentrations. Hydrobiologia 1988; 386: 103-17.

[8] Clements WH. Community responses of stream organisms to heavy metals: A review of observational and experimental approaches. In: Newman MC, McIntosh AW, Eds. Lewis, Chelsea, MI. USA. 1991; p. 363-91.

[9] Clements WH, Kiffney PM. Integrated laboratory and field approach for assessing impacts of heavy metals at the Arkansas River, Colorado. Environ Toxicol Chem 1994; 13: 397-404.

[10] Barbour MT, Gerritsen J, Snyder BD, Stribling JB. Rapid Bioassessment Protocols for use in Wadeable Streams and Rivers: Periphyton, Benthic Macroinvertebrates, and Fish, $2^{\text {nd }}$ ed. EPA841/B-99-002. U.S. Environmental Protection Agency, Office of Water, Washington, DC, 1999

[11] Specht WL, Cherry DS, Leichleitner RA, Cairns J Jr. Structural, functional, and recovery responses of stream invertebrates to fly ash effluent. Can J Fish Aquat Sci 1984; 41:18884-96.

[12] Brittain JE, Eikeland TJ. Invertebrate drift: A review. Hydrobiologia 1988; 166: 77- 93.

[13] Chon HT, Cho CH, Kim KW, Moon HS. The occurrence and dispersion of potentially toxic elements in areas covered with black shales and slates in Korea. Appl Geochem 1996; 11: 69-76.

[14] Lee J, Chon H, Kim J, Kim K, Moon H. Enrichment of potentially toxic elements in areas underlain by black shales and slates in Korea. Environ Geochem Health 1998; 20: 135-14.

[15] Ogendi GM, Farris JL, Hannigan RE. Black shale trace metal concentrations and toxicity: Preliminary findings. In: Wanty RB, Seal II RR (Eds). Balkema Publishers, NY 2004; 2: p. 1359-62.

[16] Ogendi GM, Hannigan RE, Farris JL, Smith D. The impact of black shale weathering on sediment quality. J Ark Acad Sci 2004; 58: 84-90.

[17] Ogendi GM, Brumbaugh W, Hannigan RE, Farris JL. Effects of acid volatile sulfide on black shale sediment-metal bioavailability and toxicity to midge larvae, Chironomus tentans. Environ Toxicol Chem 2007; 26: 130-9.

[18] Ogendi GM, Farris JL, Hannigan RE. Association of dissolved organic carbon with stream discharge and dissolved metals in black-shale-draining. In Sarkar D, Datta R, Hannigan R. Eds. Concepts and Applications in Environmental Chemistry: Devel Environ Sci. Elservier 2007; p. 249-74.

[19] Winterringer R. Population dynamics and reproductive patterns of the federally endangered freshwater mussel, Lampsillis streckeri (Frierson 1927). Masters thesis, Arkansas State University 2003; p. 74.

[20] Wine MS, Blumeshine SC, Hannigan RE. Endemic darter population distributions in spatially and temporally dynamic habitats: consequences for listing status. Proceedings of the Southeastern Association of Fish and Wildlife Age 2002.

[21] Bode RW, Novak MA, Abele LE. Quality assurance work plan for biological stream monitoring in New York State. Bureau of Monitoring and Assessment, Division of Water, New York State Department of Environmental Conservation, Albany, NY, USA 1991.

[22] Merritt RW, Cummins KW. An Introduction to the Aquatic Insects of North America, $3^{\text {rd }}$ ed. Kendall/Hunt, Dubuque, IA, USA 1996.

[23] Ohio Environmental Protection Agency. The Quantitative Habitat Evaluation Index (QHEI): rationale, methods and application. Ohio Environmental Protection Agency, Columbus, OH 1989.

[24] Shafer MM, Overdier JT, Hurley JP, Armstrong D, Webb D. The influence of dissolved organic carbon, suspended particulates, and 
hydrology on the concentration, partitioning and variability of trace metals intwo contrasting Wisconsin watersheds (U.S.A.). Chem Geol 1997; 136: 71-97.

[25] Clesceri LS, Greenberg AE, Eaton AD. Standard Methods for Examination of Water and Wastewater. United Book Press, Baltimore, MD 1998; p. 1220.

[26] Di Toro D M, Mahony JD, Hansen DJ, Scott KJ, Carlson AR, Ankley GT. Acid volatile sulfide predicts the acute toxicity of cadmium and nickel in sediments. Environ Sci Tech 1992; 26: 96101.

[27] Ankley GT. Evaluation of metal/acid volatile sulfide relationship in the prediction of metal bioaccumulation by benthic macroinvertebrates. Environ Toxicol Chem 1996; 15: 2138-46.

[28] NOAA. Sediment Quality Guidelines developed for the National Status and Trends Program 1999.

[29] Kiffney PM, Clements WH. Structural responses of benthic macroinvertebrate communities from different stream orders to zinc. Environ Toxicol Chem 1994; 13: 389-95.

[30] Carlisle DM, Clements WH. Sensitivity and variability of metrics used in biological assessment of running waters. Environ Toxicol Chem 1999; 18: 285-91.

[31] Schmidt TS, Soucek DJ, Cherry DS. Integrative assessment of benthic macroinvertebrate community impairment from metalcontaminated waters in tributaris of upper Powell River, Virginia, USA. Environ Toxicol Chem 2002; 21: 2233-41.

[32] Kilgour BW, Somers KM, Barton DR. A comparison of the sensitivity of stream benthic community indices to effects associated with mines, pulp and paper mills, and urbanization. Environ Toxicol Chem 2004; 23: 212-21.

[33] Clements WH, Cherry DS, Cairns J Jr. Impact of heavy-metals on insect communities in streams: Comparison of observational and experimental results. Can J Fish Aquat Sci 1988; 45: 2017-25.
[34] Plafkin JL, Barbour MT, Porter MT, Gross JK, Hughes RM. Rapid bioassessment protocols for use in streams and rivers: Benthic macroinvertebrates, and fish. 440/4-89/001. U.S. Environmental Protection Agency. Washington, DC 1989.

[35] Barbour MT, Plafkin JL, Bradley BP, Graves CG, Wisseman RW. Evaluation of EPA's rapid bioassessment benthic metrics: Metric redundancy and variability among reference streams sites. Environ Toxicol Chem 1993; 11: 437-49.

[36] Clements WH. Benthic invertebrate community response to heavy metals in the Upper Arkansas River Basin, Colorado. J North Am Benthol Soc 1994; 13: 30-44.

[37] Selby DA, Ihnat JM, Messer JJ. Effects of subacute cadmium exposure on a hardwater mountain stream microcosm. Water Res 1985; 19: 645-55.

[38] Winner RW, Van Dyke JS, Caris N, Farrel MP. Response of the macroinvertebrate fauna to a copper gradient in an experimentallypolluted stream. Internationale Vereiningung für Limnologie 1975; 19: 2121-7.

[39] Lytle DA, Peckarsky LB. Spatial and temporal impacts of diesel fuel spill on stream invertebrates. Freshwater Biol 2001; 46: 693703.

[40] Chadwick JW, Canton SP, Dent RL. Recovery of benthic invertebrate communities in Silver Bow Creek, Montana, following improved metal mine wastewater treatment. Water Air Soil Pollut 1986; $28:$ 427-38

[41] Resh VH, Jackson JK. Rapid assessment approaches to biomonitoring using benthic macroinvertebrates. In: Rosenberg DM, Resh VH (Eds). Chapman and Hall, New York, NY, USA 1993; p. 159-94. 